\title{
He Kupu nā ngā Ētita
}

Ka nui te rekareka o Te Wāhanga ki te tuku i tēnei putanga motuhake o set, ko Te Haere a ngā Ākonga Māori i ngā Ara Rapu Mātauranga te arotahinga. Katoa ngā tuhinga o tēnei putanga, mō ngā kaupapa rangahau e tāpae kōrero ana ki te ao rapu mātauranga o Aotearoa, he kitenga rangahau ko te taunakitanga tonu tōna tūāpapa. Hei aha? Hei whakapai ake i te takahi haere a ngā ākonga Māori me ō rātou whānau i ngā ara kimi mātauranga o Aotearoa.

He maha tonu ngā āhuatanga o te Māori i ngā ara rapu mātauranga ka tirohia i ngā tuhinga nei. $\bar{A}$, ka kite iho te karu pānui ko ētahi kaupapa Māori taketake pērā i te whānaungatanga, i te manaakitanga, i te rangatiratanga, i te tūrangawaewae, e paihere ana i ngā kōrero nei. Ko ia tuhinga kei te whakaatu mā te kuhu atu i ngā kaupapa Māori ki ngā mahi o te akomanga me te kura whānui, ka kaha ake te noho ora o ngā ākonga Māori me ō rātou whānau, ka kaha ake anō hoki te puta o ngā ihu o aua ākonga i ngā mahi kimi mātauranga.

Ko tētahi atu mea e kōtuitui ana i ngā tuhinga e takoto ake nei, ko te titiro ki te ākonga Māori me tōna whānau katoa atu—kāore e meatia kia noho wehe te ākonga i tōna whānau. Ko te kaha eke a te tamaiti i ngā taumata o te mātauranga, kei te āhua tonu o te torokaha o te hono o te whānau ki ngā mahi o te kura. Ko tētahi mahi hei whiri i tēnei hono, ko te whakatū marae ki te kura, ā, koinei te kaupapa o te kōrero tuatahi o tēnei putanga, "Marae ā-kura: Tracing the Birth of Marae in Schools", nā Dr Jenny Bol Jun Lee. Ko tētahi atu, ko te āta whai wāhi atu a ngā whānau ki te tārainga o te marautanga ā-kura, ā, koinei te kaupapa o te tuhinga tuarua, "Critical Issues for Whānau in English-medium Schools". E mea ana te kōrero a Dr Melinda Webber, a "Identity Matters: Racial-ethnic Identity and Māori Students", ki te mōhio te taiohi he Māori ia, ki te pai anō ōna whakaaro ki tōna taha Māori, ka pakari ake tana tū i te kura. Ehara i te mea nō roto anake o te tamaiti tēnei mea te tū pakari-he wāhi anō kei tōna whānau, kei tōna hapori e tū kaha ai. Ko tētahi o ana tino kōrero, mō ngā ākonga Māori e piki ana ki ngā taumata teitei. E ai ki tāna, kei te kākahu rātou i a rātou ki ngā tuakiri maha hei kawe haere i a rātou, à, kei te āta whakataki, kei te àta whakapuaki anō i ēnei tuakiri i ā rātou mahi i te kura me ètahi atu horopaki, e puta ai he painga ki a rātou. I tā Therese Ford "Culturally Responsive Leadership", ka horahia ngā kitenga o tana rangahau i te mahi a te tumuaki Pākehā o tētahi kura tuatahi i te tāone, i tahuri ai ia ki te whakapiki i ngā ākonga Māori mā te arotake i ngā tikanga whakaako, me te kawe ake i ētahi kaupapa whakapakari pouako e pai ake ai ngā mahi whakaako whānui i te kura.

E rua ngā kōrero kei te tuhinga He Whakaaro Anō. Nā Dr Jenny Bol Jun Lee tētahi, te Tumuaki o Te Puna Mātauranga i Te Whare Wānanga o Tāmakimakaurau. Ko ngā kawenga e tika ana mā te kaiako te kaupapa o tāna tuhinga. Ko te tuarua, nā Leeana Herewini rātou ko Dr Sarah-Jane Tiakiwai, ko Laura Hawksworth. Ko tā rāua, he āta whakaputa whakaaro mō tā rāua whai wāhi atu ki tētahi kaupapa poipoi i ngā ākonga hautupua kei ngā kura kaupapa Māori o Waikato.

I te Q \& A, ka takoto te pātai a tētahi kaiako, a Mark Bradley, o te Kāreti o Pōneke, mō Ka Hikitia. Ka whakautua e Liz Patara, tumuaki o Clyde Quay School, i Pōneke. Kua tuhia anō e Mere Berryman he kōrero ki Assessment News mō te Aromatawai reo à-waha, he rauemi hei āwhina i te aromatawainga o te reo à-waha o ngā ākonga i ngā akomanga rumaki Māori.

Kei te mihi atu ki ngā kaituhi katoa, tae atu ki te hunga àta tirotiro i ngā kōrero. Me kore ake tā koutou tautoko i tēnei putanga ahurei o set. Ko te tūmanako he whakaaro, he māramatanga kei ngā whārangi e hora ake nei mōu, mō tō koutou kura, he ara whakapai ake i te pūnaha mātauranga o Aotearoa, e kaha ake ai te noho ora o ngā ākonga Māori me ō rātou whānau, e tino eke ai ngā ākonga Māori ki ngā taumata o te ao mātauranga e tika ana.

Nā Dr Jessica Hutchings māua ko Nicola Bright Te Wähanga, NZCER 


\section{Editorial}

It is with pleasure that Te Wāhanga introduces this special edition of set focusing on Te Māori i ngā Ara Rapu Mātauranga-Māori Education. All articles in this edition are based on the work of researchers who are aiming to provide the education system in Aotearoa New Zealand with evidence-based research findings that can contribute to improving the educational experience of Māori students and their whānau.

This edition explores many key themes in the field of Māori education. Kaupapa (Māori principles) such as whānaungatanga, manaakitanga, rangatiratanga and tūrangawaewae are core themes that run through the articles. Each article highlights in some way how bringing kaupapa into classroom practice and into the operation of a school results in clear wellbeing and achievement benefits for Māori students and their whānau.

A further commonality in this edition is that all the articles view Māori students as part of their whānau. The success of Māori learners in the schooling system is interrelated with the connectedness of the whānau to the school. This connection can occur through both the whānau and the school community developing school marae - as is described in the opening article by Dr Jenny Bol Jun Lee, "Marae ā-kura: Tracing the Birth of Marae in Schools" - to whānau being involved in shaping the school curriculum, as noted in the second article, "Critical Issues for Whānau in English-medium Schools”. Dr Melinda Webber's article, "Identity Matters: Racial-ethnic Identity and Māori Students", proposes that a positive sense of racial-ethnic identity can assist Māori adolescents to be resilient at school. Resilience comes not only from individuals, but from the support of whānau and communities. Her article raises an important point with regard both to high-achieving Māori students adopting multiple identities to represent themselves, and to students' strategic management of the representation of these identities in school and other contexts to their advantage. Therese Ford's article, "Culturally Responsive Leadership", presents the findings of a case study that looked at how a non-Māori principal in an urban primary school responded successfully to lifting Māori student achievement through reviewing teaching practice and implementing professional learning and development programmes to enhance school pedagogy.

Two articles are presented in He Whakaaro Anō. One is by Dr Jenny Bol Jun Lee, Head of School at Te Puna Mātauranga, the School of Māori Education at Auckland University, about the roles of educators. The other, by Leeana Herewini, Dr Sarah-Jane Tiakiwai and Laura Hawksworth, critically reflects on their involvement and experience in gifted education with kura kaupapa Māori in the Waikato.

Q \& A features a teacher's question about Ka Hikitia, posed by Mark Bradley of Wellington College, which is answered by Liz Patara, principal at Clyde Quay School, Wellington. Mere Berryman presents a piece in Assessment News on Aromatawai reo ā-waha, oral Māori language assessment tools to support the Māori-medium sector.

We thank all of the authors and reviewers for their commitment to contributing to this special edition of set. We hope that this edition provides you and your school with some further ideas and understandings about how we can strengthen the education system in Aotearoa New Zealand to enhance the wellbeing and achievement of Māori students and their whānau.

Dr Jessica Hutchings and Nicola Bright Te Wāhanga, NZCER 